\title{
Susceptibility of important Gram-negative pathogens to tigecycline and other antibiotics in Latin America between 2004 and 2010
}

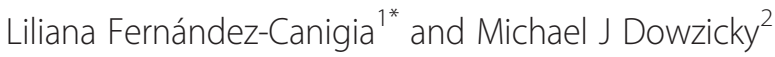

\begin{abstract}
Background: The Tigecycline Evaluation and Surveillance Trial (T.E.S.T.) is a global surveillance study of antimicrobial susceptibility. This study reports data from Gram-negative isolates collected from centers in Latin America between 2004 and 2010.

Methods: Consecutive bacterial isolates were tested at each center using broth microdilution methodology as described by the Clinical Laboratory Standards Institute (CLSI). Susceptibility was determined using the CLSI interpretive criteria. For tigecycline the US Federal Drug Administration (FDA) criteria were used.

Results: A total of 16232 isolates were analyzed. Susceptibility to imipenem, meropenem, and tigecycline was $>95 \%$ against both non-extended-spectrum $\beta$-lactamase (ESBL) and ESBL producing Escherichia coli. Susceptibility to amikacin was also $>95 \%$ for non-ESBL E. coli. $24.3 \%$ of E. coli were ESBL producers, ranging from $11.2 \%(58 / 519)$ in Colombia to $40.3 \%$ (31/77) in Honduras. Greater than 90\% of non-ESBL Klebsiella pneumoniae were susceptible to tigecycline, carbapenems and amikacin. 35.3\% of K. pneumoniae were ESBL producers, ranging from 17.2\% (36/209) in Venezuela to $73.3 \%$ (55/75) in Honduras, with only imipenem and tigecycline maintaining $>90 \%$ susceptibility. Greater than 90\% of Klebsiella oxytoca, Enterobacter spp., and Serratia marcescens were susceptible to amikacin, carbapenems and tigecycline. The highest rates of susceptibility against Acinetobacter baumannii were seen for minocycline (89.4\%) and imipenem (62.5\%), while $95.8 \%$ of the A. baumannii isolates displayed an MIC $\leq 2 \mu \mathrm{g} / \mathrm{mL}$ for tigecycline.

Conclusions: In this study carbapenems and tigecycline remain active against Enterobacteriaceae and $A$. baumannii; however, there is cause for concern with carbapenem non-susceptible isolates reported in all countries included in this study.
\end{abstract}

Keywords: Tigecycline, Latin America, Resistance, Susceptibility, Carbapenems

\section{Background}

Tigecycline is a glycylcycline licensed by the US Food and Drug Administration (FDA) for the treatment of complicated skin and skin structure infections (cSSSI), complicated intra-abdominal infections (cIAIs) and community acquired bacterial pneumonia (CAP). The Tigecycline Evaluation and Surveillance Trial (T.E.S.T.) is a global surveillance study with the aim of assessing and reporting the antimicrobial susceptibility of tigecycline and comparator agents globally, regionally, and for

\footnotetext{
*Correspondence: Ifcanigia@labdl.com.ar

'Laboratorio de Microbiología, Hospital Aleman, Pueyrredón 1640, PB, Ciudad Autónoma de Buenos Aires, Argentina

Full list of author information is available at the end of the article
}

individual countries. T.E.S.T. was initiated in 2004 and to date 60 countries have contributed with Grampositive and Gram-negative isolates and susceptibility data. Antimicrobial surveillance studies, such as T.E.S.T., play a key role in charting antimicrobial resistance.

The Latin American region is recognized as facing a significant challenge with high levels of antimicrobial resistance among important Gram-negative organisms including Escherichia coli and Klebsiella spp. and the non-fermenters Acinetobacter spp. and Pseudomonas aeruginosa [1-3]. In recent years, extended-spectrum $\beta$ lactamases (ESBLs) have increased in type and frequency among Enterobacteriaceae and carbapenemases have emerged $[4,5]$. In the case of the non-fermentative

\section{Biomed Central}


Gram-negative bacilli multidrug-resistance is an increasing problem with limited, or no treatment option [6].

In this report we present data from the Latin American region of Gram-negative isolates collected between 2004 and 2010. The isolates collected between 2004 and 2007 were previously reported by Rossi et al. [7].

\section{Methods}

\section{Organism collection}

Gram-negative isolates were collected from 12 countries in Latin America between 2004 and 2010. Centers were distributed as follows: 12 in Argentina, 3 in Brazil, 5 in Chile, 14 in Colombia, 1 in El Salvador, 4 in Guatemala, 2 in Honduras, 1 in Jamaica, 15 in Mexico, 1 in Nicaragua, 2 in Panama, and 6 in Venezuela. The Gram-negative isolates submitted were consecutive and determined to be clinically significant using local criteria. Permissible clinical sources included blood, respiratory tract, urine (limited to no more than $25 \%$ of all isolates), skin, wound, and fluids. For each year, each participant center was required to identify and conduct susceptibility tests on Acinetobacter spp. (15), E. coli (25), Enterobacter spp. (25), Serratia spp. (10), Klebsiella spp. (25) and Haemophylus influenzae (15). A single isolate per patient was accepted. Inclusion in the study was independent of the patient's medical history, previous antimicrobial use, sex and age. No banked or stored isolates were accepted.

\section{Antimicrobial susceptibility testing}

Each study center carried out antimicrobial susceptibility testing using broth microdilution methodology (Sensititre ${ }^{\circledR}$ plates [TREK Diagnostic Systems, West Sussex, England] or MicroScan ${ }^{\circledR}$ panels [Siemens, Sacramento, CA, USA]) as described by the Clinical and Laboratory Standards Institute (CLSI) [8]. Gram-negative isolates were tested against amikacin, amoxicillin-clavulanate, ampicillin, cefepime, ceftazidime, ceftriaxone, imipenem, levofloxacin, meropenem, minocycline, piperacillin-tazobactam, and tigecycline. In 2006, unreliability of the imipenem testing led to a switch from MicroScan ${ }^{\circledR}$ panels with imipenem to Sensititre ${ }^{\circledR}$ plates with meropenem. The presence or abscence of $\beta$-lactamase among $H$. influen$z a e$ was determined using the preferred method of each center.

Quality control strains used in the testing were E. coli ATCC 25922 and $P$. aeruginosa ATCC 27853. Confirmation of isolate identification and management of a centralized database were performed by a central laboratory (Laboratories International for Microbiology Studies, a division of International Health Management Associates, Inc. [IHMA, Schaumburg, IL, USA]).

Antimicrobial susceptibility was determined using CLSI interpretive criteria $[9,10]$. For tigecycline, the FDA approved breakpoints, as provided in the package insert, were used [11].

\section{Extended spectrum $\beta$-lactamase (ESBL) determination}

Testing for ESBL production was carried out on isolates of E. coli and Klebsiella spp. according to the CLSI guidelines [9]. The methodology used Mueller-Hinton agar (Remel, Inc., Lenexa, KS, USA) and cefotaxime (30 $\mu \mathrm{g})$, cefotaxime-clavulanic acid $(30 / 10 \mu \mathrm{g})$, ceftazidime (30 $\mu \mathrm{g})$, and ceftazidime-clavulanic acid $(30 / 10 \mu \mathrm{g})$ discs (Oxoid, Inc., Ogdensburg, NY, USA). Quality control was carried out using K. pneumoniae ATCC 700603 (ESBLpositive) and E. coli ATCC 25922 (ESBL-negative).

\section{Multidrug-resistant Acinetobacter baumannii}

Multidrug resistance among isolates of A. baumannii was defined as resistance to levofloxacin, amikacin, carbapenems (imipenem and/or meropenem), ceftazidime and piperacillin-tazobactam.

\section{Results}

Antimicrobial susceptibility data on 16232 Gramnegative isolates collected in Latin America between 2004 and 2010 are presented in Table 1 . Susceptibility among the E. coli isolates (both ESBL and non-ESBL producers) was $>95 \%$ for carbapenems and tigecycline. Susceptibility to amikacin was also $>95 \%$ against nonESBL producing E. coli $\left(\mathrm{MIC}_{90} 8 \mu \mathrm{g} / \mathrm{mL}\right)$ but decreased to $89.7 \%$ against ESBL producers $\left(\mathrm{MIC}_{90} 32 \mu \mathrm{g} / \mathrm{mL}\right.$ ). A total of $24.3 \%$ of the $E$. coli collected from Latin America were identified as ESBL producers with percentages of ESBL production varying from $11.2 \%(58 / 519)$ in Colombia to $40.3 \%$ (31/77) in Honduras (Figure 1). Data on susceptibility to imipenem and meropenem by country are presented in Table 2. Among E. coli isolates, ESBL producers displayed slightly lower susceptibility to meropenem than non-ESBL producing isolates.

The most active antimicrobial agents against nonESBL producing $K$. pneumoniae were tigecycline $\left(\mathrm{MIC}_{90}\right.$ $1 \mu \mathrm{g} / \mathrm{mL}$ ), carbapenems (imipenem $\mathrm{MIC}_{90} 0.5 \mu \mathrm{g} / \mathrm{mL}$ and meropenem $\left.\mathrm{MIC}_{90} 0.25 \mu \mathrm{g} / \mathrm{mL}\right)$ and amikacin $\left(\mathrm{MIC}_{90} 8 \mu \mathrm{g} / \mathrm{mL}\right.$ ) (Table 1). All tested antimicrobial agents displayed reduced activity against ESBL-producing $K$. pneumoniae, with only imipenem and tigecycline recording percentage susceptibilities of $>90 \%$ ( $96.0 \%$ and 93.7\%, respectively). In particular, susceptibilities to levofloxacin against ESBL-producing isolates of E. coli and $K$. pneumoniae were lower when compared with nonESBL-producing strains (11.5\% vs. $60.9 \%$ and $38.2 \%$ vs $80.1 \%$, respectively) (Table 1 ). Among $K$. pneumoniae $35.3 \%$ were ESBL producers and percentages ranged from $17.2 \%(36 / 209)$ in Venezuela to $73.3 \%$ (55/75) in Honduras (Figure 1). Both ESBL and non-ESBL- 
Table 1 Antimicrobial activity against Gram-negative organisms collected from Latin America (2004 - 2010)

\begin{tabular}{|c|c|c|c|c|c|c|c|}
\hline \multirow[t]{2}{*}{ Organisms/antimicrobial } & \multirow[b]{2}{*}{$\mathbf{N}$} & \multicolumn{3}{|c|}{ MIC (mg/L) } & \multicolumn{3}{|c|}{ Percentage } \\
\hline & & 50 & 90 & Range & $S$ & 1 & $\mathbf{R}$ \\
\hline \multicolumn{8}{|l|}{ non-ESBL E. coli } \\
\hline Amikacin & 2711 & 2 & 8 & $\leq 0.5$ to $\geq 128$ & 97.2 & 1.2 & 1.7 \\
\hline Amoxi/clav & 2711 & 8 & 32 & $\leq 0.12$ to $\geq 64$ & 60.5 & 21.2 & 18.4 \\
\hline Ampicillin & 2711 & $\geq 64$ & $\geq 64$ & $\leq 0.5$ to $\geq 64$ & 28.6 & 1.5 & 69.9 \\
\hline Cefepime & 2711 & $\leq 0.5$ & 4 & $\leq 0.5$ to $\geq 64$ & 94.3 & 2.1 & 3.6 \\
\hline Ceftazidime $^{a}$ & 2711 & $\leq 8$ & 16 & $\leq 1$ to $\geq 64$ & - & - & 11.7 \\
\hline Ceftriaxone & 2711 & $\leq 0.06$ & 32 & $\leq 0.06$ to $\geq 128$ & 82.0 & 2.3 & 15.6 \\
\hline Imipenem & 485 & 0.25 & 0.5 & $\leq 0.06$ to $\geq 32$ & 98.6 & 0.6 & 0.8 \\
\hline Levofloxacin & 2711 & 0.25 & $\geq 16$ & $\leq 0.008$ to $\geq 16$ & 60.9 & 3.0 & 36.2 \\
\hline Meropenem & 2226 & $\leq 0.06$ & 0.12 & $\leq 0.06$ to $\geq 32$ & 98.6 & 0.4 & 1.0 \\
\hline Minocycline & 2711 & 4 & 16 & $\leq 0.5$ to $\geq 32$ & 62.4 & 14.3 & 23.2 \\
\hline Pip/taz & 2711 & 2 & 32 & $\leq 0.06$ to $\geq 256$ & 88.8 & 5.2 & 6.0 \\
\hline Tigecycline & 2711 & 0.25 & 0.5 & $\leq 0.008$ to $\geq 32$ & 99.7 & 0.2 & $<0.1^{c}$ \\
\hline \multicolumn{8}{|l|}{ ESBL E. coli } \\
\hline Amikacin & 870 & 4 & 32 & $\leq 0.5$ to $\geq 128$ & 89.7 & 5.1 & 5.3 \\
\hline Amoxi/clav & 870 & 16 & 32 & 0.25 to $\geq 64$ & 21.1 & 42.5 & 36.3 \\
\hline Cefepime & 870 & 32 & $\geq 64$ & $\leq 0.5$ to $\geq 64$ & 28.2 & 14.3 & 57.6 \\
\hline Ceftazidime $^{a}$ & 870 & 16 & $\geq 64$ & $\leq 1$ to $\geq 64$ & - & - & 65.5 \\
\hline Ceftriaxone & 870 & $\geq 128$ & $\geq 128$ & $\leq 0.06$ to $\geq 128$ & 1.1 & 2.0 & 96.9 \\
\hline Imipenem & 143 & 0.25 & 0.5 & $\leq 0.06$ to 8 & 97.9 & 0.7 & 1.4 \\
\hline Levofloxacin & 870 & $\geq 16$ & $\geq 16$ & 0.015 to $\geq 16$ & 11.5 & 3.4 & 85.1 \\
\hline Meropenem & 727 & $\leq 0.06$ & 0.12 & $\leq 0.06$ to $\geq 32$ & 96.4 & 1.2 & 2.3 \\
\hline Minocycline & 870 & 4 & $\geq 32$ & $\leq 0.5$ to $\geq 32$ & 52.3 & 14.6 & 33.1 \\
\hline Pip/taz & 870 & 8 & 64 & $\leq 0.06$ to $\geq 256$ & 73.9 & 16.1 & 10.0 \\
\hline Tigecycline & 870 & 0.25 & 0.5 & $\leq 0.008$ to 4 & 99.8 & 0.2 & 0.0 \\
\hline \multicolumn{8}{|l|}{ Non-ESBL K. pneumoniae } \\
\hline Amikacin & 1917 & 2 & 8 & $\leq 0.5$ to $\geq 128$ & 93.4 & 1.8 & 4.8 \\
\hline Amoxi/clav & 1917 & 4 & $\geq 64$ & 0.25 to $\geq 64$ & 67.5 & 10.0 & 22.5 \\
\hline Cefepime & 1917 & $\leq 0.5$ & 16 & $\leq 0.5$ to $\geq 64$ & 87.7 & 2.8 & 9.4 \\
\hline Ceftazidime $^{a}$ & 1917 & $\leq 8$ & 32 & $\leq 1$ to $\geq 64$ & - & - & 17.2 \\
\hline Ceftriaxone & 1917 & $\leq 0.06$ & $\geq 128$ & $\leq 0.06$ to $\geq 128$ & 77.1 & 1.4 & 21.5 \\
\hline Imipenem & 275 & 0.5 & 0.5 & $\leq 0.06$ to $\geq 32$ & 98.9 & 0.0 & 1.1 \\
\hline Levofloxacin & 1917 & 0.06 & $\geq 16$ & $\leq 0.008$ to $\geq 16$ & 80.1 & 2.1 & 17.7 \\
\hline Meropenem & 1642 & $\leq 0.06$ & 0.25 & $\leq 0.06$ to $\geq 32$ & 94.6 & 1.0 & 4.4 \\
\hline Minocycline & 1917 & 4 & $\geq 32$ & $\leq 0.5$ to $\geq 32$ & 65.8 & 11.1 & 23.1 \\
\hline Pip/taz & 1917 & 4 & $\geq 256$ & $\leq 0.06$ to $\geq 256$ & 79.6 & 6.2 & 14.2 \\
\hline Tigecycline & 1917 & 0.5 & 1 & $\leq 0.008$ to $\geq 32$ & 96.9 & 2.3 & 0.8 \\
\hline \multicolumn{8}{|l|}{ ESBL $K$. pneumoniae } \\
\hline Amikacin & 1045 & 8 & $\geq 128$ & $\leq 0.5$ to $\geq 128$ & 71.2 & 8.3 & 20.5 \\
\hline Amoxi/clav & 1045 & 32 & $\geq 64$ & $\leq 0.12$ to $\geq 64$ & 13.1 & 30.6 & 56.3 \\
\hline Cefepime & 1045 & 32 & $\geq 64$ & $\leq 0.5$ to $\geq 64$ & 29.2 & 12.1 & 58.8 \\
\hline Ceftazidime $^{a}$ & 1045 & 32 & $\geq 64$ & $\leq 2$ to $\geq 64$ & - & - & 81.1 \\
\hline Ceftriaxone & 1045 & $\geq 128$ & $\geq 128$ & $\leq 0.06$ to $\geq 128$ & 1.0 & 1.2 & 97.8 \\
\hline Imipenem & 199 & 0.5 & 1 & $\leq 0.06$ to 16 & 96.0 & 2.5 & 1.5 \\
\hline Levofloxacin & 1045 & 8 & $\geq 16$ & $\leq 0.008$ to $\geq 16$ & 38.2 & 5.5 & 56.4 \\
\hline Meropenem & 846 & $\leq 0.06$ & 2 & $\leq 0.06$ to $\geq 32$ & 89.0 & 2.4 & 8.6 \\
\hline
\end{tabular}


Table 1 Antimicrobial activity against Gram-negative organisms collected from Latin America (2004 - 2010) (Continued)

\begin{tabular}{|c|c|c|c|c|c|c|c|}
\hline Minocycline & 1045 & 8 & $\geq 32$ & $\leq 0.5$ to $\geq 32$ & 49.0 & 17.1 & 33.9 \\
\hline Pip/taz & 1045 & 64 & $\geq 256$ & 0.12 to $\geq 256$ & 34.5 & 20.8 & 44.7 \\
\hline Tigecycline & 1045 & 0.5 & 2 & 0.03 to 16 & 93.7 & 4.9 & 1.4 \\
\hline \multicolumn{8}{|l|}{ K. oxytoca } \\
\hline Amikacin & 311 & 2 & 8 & $\leq 0.5$ to $\geq 128$ & 94.9 & 1.6 & 3.5 \\
\hline Amoxi/clav & 311 & 4 & 32 & 0.25 to $\geq 64$ & 69.1 & 11.9 & 19.0 \\
\hline Cefepime & 311 & $\leq 0.5$ & 16 & $\leq 0.5$ to $\geq 64$ & 85.5 & 5.8 & 8.7 \\
\hline Ceftazidime $^{a}$ & 311 & $\leq 8$ & 32 & $\leq 1$ to $\geq 64$ & - & - & 20.9 \\
\hline Ceftriaxone & 311 & 0.12 & $\geq 128$ & $\leq 0.06$ to $\geq 128$ & 68.5 & 2.9 & 28.6 \\
\hline Imipenem & 76 & 0.5 & 0.5 & $\leq 0.06$ to 1 & 100 & 0.0 & 0.0 \\
\hline Levofloxacin & 311 & 0.06 & $\geq 16$ & $\leq 0.008$ to $\geq 16$ & 81.0 & 1.3 & 17.7 \\
\hline Meropenem & 235 & $\leq 0.06$ & 0.12 & $\leq 0.06$ to 16 & 97.4 & 1.3 & 1.3 \\
\hline Minocycline & 311 & 2 & 16 & $\leq 0.5$ to $\geq 32$ & 77.5 & 10.3 & 12.2 \\
\hline Pip/taz & 311 & 2 & 128 & $\leq 0.06$ to $\geq 256$ & 83.6 & 6.1 & 10.3 \\
\hline Tigecycline & 311 & 0.25 & 1 & 0.06 to 4 & 97.7 & 2.3 & 0.0 \\
\hline
\end{tabular}

Enterobacter spp.

\begin{tabular}{|c|c|c|c|c|c|c|c|}
\hline Amikacin & 2804 & 2 & 32 & $\leq 0.5$ to $\geq 128$ & 89.2 & 4.4 & 6.5 \\
\hline Amoxi/clav & 2804 & $\geq 64$ & $\geq 64$ & $\leq 0.12$ to $\geq 64$ & 4.7 & 3.0 & 92.3 \\
\hline Cefepime & 2804 & $\leq 0.5$ & $\geq 64$ & $\leq 0.5$ to $\geq 64$ & 81.4 & 4.6 & 14.1 \\
\hline Ceftazidime $^{a}$ & 2804 & $\leq 8$ & $\geq 64$ & $\leq 1$ to $\geq 64$ & - & - & 40.5 \\
\hline Ceftriaxone & 2804 & 1 & $\geq 128$ & $\leq 0.06$ to $\geq 128$ & 51.9 & 2.6 & 45.5 \\
\hline Imipenem & 493 & 0.5 & 1 & $\leq 0.06$ to $\geq 32$ & 95.9 & 2.6 & 1.4 \\
\hline Levofloxacin & 2804 & 0.12 & $\geq 16$ & $\leq 0.008$ to $\geq 16$ & 78.2 & 3.1 & 18.8 \\
\hline Meropenem & 2311 & $\leq 0.06$ & 0.5 & $\leq 0.06$ to $\geq 32$ & 94.3 & 1.9 & 3.8 \\
\hline Minocycline & 2804 & 4 & $\geq 32$ & $\leq 0.5$ to $\geq 32$ & 61.9 & 17.7 & 20.3 \\
\hline Pip/taz & 2804 & 4 & $\geq 256$ & $\leq 0.06$ to $\geq 256$ & 70.1 & 11.7 & 18.1 \\
\hline Tigecycline & 2804 & 0.5 & 2 & $\leq 0.008$ to $\geq 32$ & 96.0 & 3.5 & 0.5 \\
\hline \multicolumn{8}{|l|}{ S. marcescens } \\
\hline Amikacin & 1126 & 2 & 64 & $\leq 0.5$ to $\geq 128$ & 82.6 & 7.2 & 10.2 \\
\hline Amoxi/clav & 1126 & $\geq 64$ & $\geq 64$ & $\leq 0.12$ to $\geq 64$ & 4.4 & 2.9 & 92.6 \\
\hline Cefepime & 1126 & $\leq 0.5$ & 32 & $\leq 0.5$ to $\geq 64$ & 83.6 & 3.7 & 12.7 \\
\hline Ceftazidime $^{a}$ & 1126 & $\leq 8$ & 32 & $\leq 1$ to $\geq 64$ & - & - & 17.5 \\
\hline Ceftriaxone & 1126 & 0.5 & $\geq 128$ & $\leq 0.06$ to $\geq 128$ & 67.8 & 3.4 & 28.9 \\
\hline Imipenem & 229 & 0.5 & 1 & $\leq 0.06$ to 8 & 91.7 & 6.1 & 2.2 \\
\hline Levofloxacin & 1126 & 0.25 & 4 & $\leq 0.008$ to $\geq 16$ & 86.2 & 4.4 & 9.3 \\
\hline Meropenem & 897 & $\leq 0.06$ & 0.25 & $\leq 0.06$ to 8 & 96.2 & 1.8 & 2.0 \\
\hline Minocycline & 1126 & 4 & 16 & $\leq 0.5$ to $\geq 32$ & 61.3 & 23.6 & 15.1 \\
\hline Pip/taz & 1126 & 2 & 64 & $\leq 0.06$ to $\geq 256$ & 84.0 & 6.9 & 9.1 \\
\hline Tigecycline & 1126 & 1 & 2 & $\leq 0.008$ to 16 & 95.5 & 3.7 & 0.8 \\
\hline \multicolumn{8}{|l|}{ H. influenzae } \\
\hline Amoxi/clav & 908 & 0.5 & 1 & $\leq 0.12$ to 16 & 99.3 & 0.0 & 0.7 \\
\hline Ampicillin & 908 & $\leq 0.5$ & 16 & $\leq 0.5$ to $\geq 64$ & 78.7 & 2.5 & 18.7 \\
\hline Cefepime & 908 & $\leq 0.5$ & $\leq 0.5$ & $\leq 0.5$ to 8 & 99.6 & - & - \\
\hline Ceftazidime $^{\mathrm{b}}$ & 902 & $\leq 8$ & $\leq 8$ & $\leq 8$ to 16 & - & - & - \\
\hline Ceftriaxone & 908 & $\leq 0.06$ & $\leq 0.06$ & $\leq 0.06$ to 2 & 100 & - & - \\
\hline Imipenem & 217 & 0.5 & 1 & $\leq 0.06$ to 4 & 100 & - & - \\
\hline$\underline{\text { Levofloxacin }}$ & 908 & 0.015 & 0.03 & $\leq 0.008$ to 2 & 100 & - & - \\
\hline Meropenem & 691 & $\leq 0.06$ & 0.12 & $\leq 0.06$ to 0.5 & 100 & - & - \\
\hline
\end{tabular}


Table 1 Antimicrobial activity against Gram-negative organisms collected from Latin America (2004 - 2010) (Continued)

\begin{tabular}{|c|c|c|c|c|c|c|c|}
\hline Minocycline & 908 & $\leq 0.5$ & 1 & $\leq 0.5$ to 16 & 98.7 & 0.8 & 0.6 \\
\hline Pip/taz & 908 & $\leq 0.06$ & $\leq 0.06$ & $\leq 0.06$ to 4 & 99.7 & 0.0 & 0.3 \\
\hline Tigecycline & 908 & 0.12 & 0.25 & $\leq 0.008$ to 0.5 & 98.8 & - & - \\
\hline \multicolumn{8}{|l|}{ A. baumannii } \\
\hline Amikacin & 1806 & 64 & $\geq 128$ & $\leq 0.5$ to $\geq 128$ & 30.4 & 12.0 & 57.6 \\
\hline Cefepime & 1806 & 32 & $\geq 64$ & $\leq 0.5$ to $\geq 64$ & 25.3 & 14.4 & 60.3 \\
\hline Ceftazidime & 1806 & $\geq 64$ & $\geq 64$ & $\leq 1$ to $\geq 64$ & 18.5 & 7.8 & 73.8 \\
\hline Ceftriaxone & 1806 & $\geq 128$ & $\geq 128$ & $\leq 0.06$ to $\geq 128$ & 10.5 & 11.1 & 78.4 \\
\hline Imipenem & 307 & 2 & $\geq 32$ & $\leq 0.06$ to $\geq 32$ & 62.5 & 3.9 & 33.6 \\
\hline Levofloxacin & 1806 & 8 & $\geq 16$ & $\leq 0.008$ to $\geq 16$ & 20.9 & 11.4 & 67.8 \\
\hline Meropenem & 1499 & $\geq 32$ & $\geq 32$ & $\leq 0.06$ to $\geq 32$ & 33.9 & 5.5 & 60.6 \\
\hline Minocycline & 1806 & $\leq 0.5$ & 8 & $\leq 0.5$ to $\geq 32$ & 89.4 & 4.6 & 6.0 \\
\hline Pip/taz & 1806 & $\geq 256$ & $\geq 256$ & $\leq 0.06$ to $\geq 256$ & 18.7 & 9.1 & 72.2 \\
\hline Tigecycline & 1806 & 0.5 & 2 & $\leq 0.008$ to $\geq 32$ & - & - & - \\
\hline \multicolumn{8}{|l|}{ P. aeruginosa } \\
\hline Amikacin & 2734 & 4 & $\geq 128$ & $\leq 0.5$ to $\geq 128$ & 71.8 & 8.1 & 20.0 \\
\hline Cefepime & 2734 & 8 & $\geq 64$ & $\leq 0.5$ to $\geq 64$ & 59.8 & 15.2 & 25.1 \\
\hline Ceftazidime & 2734 & $\leq 8$ & $\geq 64$ & $\leq 1$ to $\geq 64$ & 54.9 & 10.6 & 34.5 \\
\hline Imipenem & 461 & 1 & 16 & 0.12 to $\geq 32$ & 66.8 & 15.0 & 18.2 \\
\hline Levofloxacin & 2734 & 2 & $\geq 16$ & 0.015 to $\geq 16$ & 52.6 & 6.1 & 41.4 \\
\hline Meropenem & 2273 & 2 & $\geq 32$ & $\leq 0.06$ to $\geq 32$ & 64.2 & 9.6 & 26.2 \\
\hline Minocycline & 2734 & 16 & $\geq 32$ & $\leq 0.5$ to $\geq 32$ & - & - & - \\
\hline Pip/taz & 2734 & 16 & $\geq 256$ & $\leq 0.06$ to $\geq 256$ & 75.3 & 0.0 & 24.7 \\
\hline Tigecycline & 2734 & 8 & $\geq 32$ & $\leq 0.008$ to $\geq 32$ & - & - & - \\
\hline
\end{tabular}

S, susceptible; I, intermediate; R, resistant; amoxi/clav, amoxicillin-clavulanate; pip/taz, piperacillin-tazobactam.

- No CLSI breakpoints available.

${ }^{a}$ The ceftazidime testing range against the Enterobacteriaceae started at $8 \mu \mathrm{g} / \mathrm{mL}$, therefore susceptible and intermediate classifications can not be calculated.

b The ceftazidime testing range against $H$. influenzae started at $8 \mu \mathrm{g} / \mathrm{mL}$, therefore a susceptible classification can not be calculated.

c $0.04 \%, 1$ isolate, collected in 2009. The isolate was collected in Mexico in 2009 from a male inpatient. The isolate was also resistant to amoxicillin-clavulanate, ampicillin, ceftriaxone, and minocycline.

producing $K$. pneumoniae displayed higher resistance levels to carbapenemes than $E$. coli in all countries (Table 2).

Amikacin, carbapenems and tigecycline were the most active agents against $K$. oxytoca ( $>94 \%$ susceptibility) and Enterobacter spp. ( $>89 \%$ susceptibility). Against isolates of $S$. marcescens the carbapenems and tigecycline were the most active agents ( $>91 \%$ susceptibility) (Table 1). Among these three species rates of susceptibility to the carbapenems were $\geq 90 \%$ in all countries where data were available, with the exception of susceptibility to meropenem among isolates of Enterobacter spp. collected in Guatemala and Honduras (79.0\% and $85.3 \%$, respectively) and susceptibility to imipenem among isolates of $S$. marcescens from Mexico (88.5\%) (Table 2).

Almost all of antimicrobials in the panel were active against $H$. influenzae with susceptibility varying from $78.7 \%$ for ampicillin to $100 \%$ for ceftriaxone, imipenem, levofloxacin, and meropenem (Table 1). Almost $20 \%$ of isolates (181/908) were $\beta$-lactamase producers.
For A. baumannii susceptibility was less than $50 \%$ for seven of the nine antimicrobial agents (Table 1). The most active agents were minocycline $\left(89.4 \%, \mathrm{MIC}_{90}\right.$ $8 \mu \mathrm{g} / \mathrm{mL}$ ) and imipenem (62.5\%, $\mathrm{MIC}_{90} \geq 32 \mu \mathrm{g} / \mathrm{mL}$ ). Tigecycline showed good activity against $A$. baumannii: although no breakpoints are available for this agent, $95.8 \%$ of the isolates displayed an MIC $\leq 2 \mu \mathrm{g} / \mathrm{mL}$. Low rates of carbapenem susceptibility were observed in most countries (Table 2); the lowest rates were reported for meropenem among isolates from Argentina (15.0\%) and Panama (16.7\%). A total of 600 isolates (33.2\%) were multidrug-resistant, among them the $\mathrm{MIC}_{90}$ for minocycline and tigecycline were 8 and $2 \mu \mathrm{g} / \mathrm{mL}$, respectively.

Among $P$. aeruginosa collected the most active agents were piperacillin-tazobactam, with $75.3 \%$ of isolates susceptible $\left(\mathrm{MIC}_{90} \geq 256 \mu \mathrm{g} / \mathrm{mL}\right.$ ), and amikacin with $71.8 \%$ $\left(\mathrm{MIC}_{90} \geq 128 \mu \mathrm{g} / \mathrm{mL}\right.$ ) (Table 1).

\section{Discussion}

This study reports on rates of antimicrobial susceptibility among important Gram-negative organisms collected 


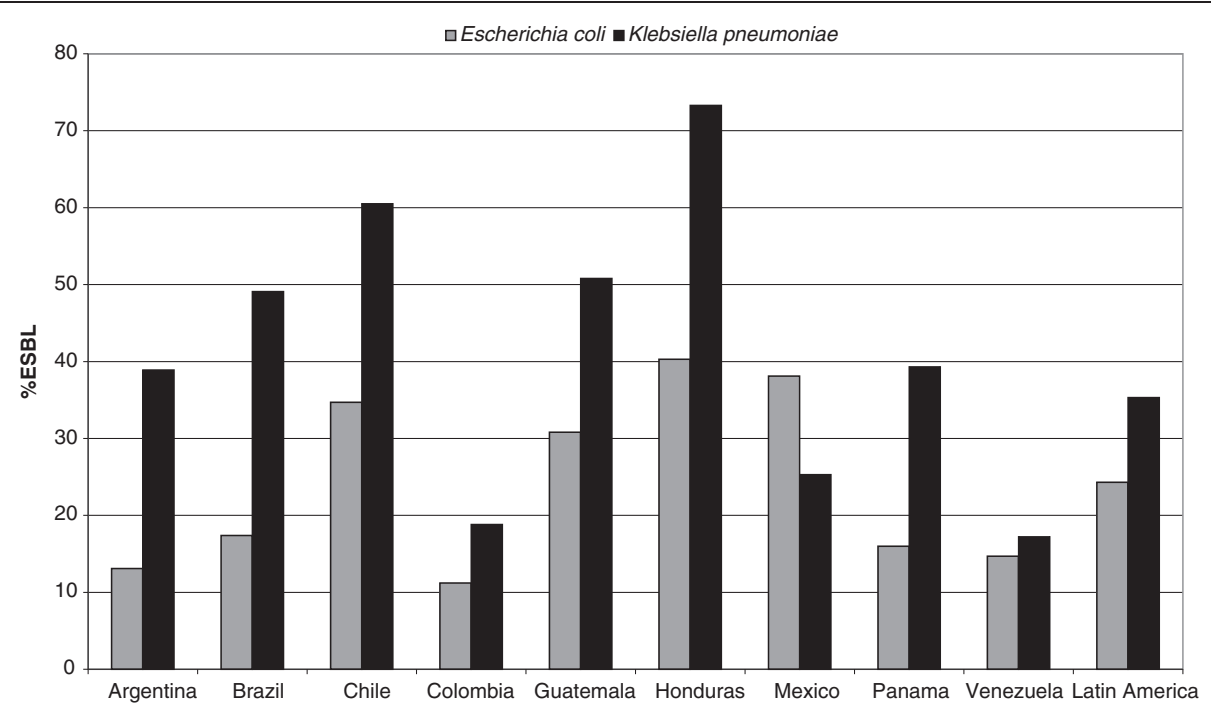

Figure 1 Percentage of Escherichia coli and Klebsiella pneumoniae isolates identified as ESBL producers in each Latin American country ${ }^{\mathrm{a}}$ involved in T.E.S.T. (2004-2010). E. coli N values: Argentina, 101/769; Brazil, 43/247; Chile, 94/271; Colombia, 58/519; Guatemala, 81/263; Honduras, 31/77; Mexico, 398/1044; Panama, 16/100; Venezuela, 32/218; Latin America, 870/3581. K. pneumoniae N values: Argentina, 270/694; Brazil, 105/214; Chile, 147/243; Colombia, 81/432; Guatemala, 96/189; Honduras, 55/75; Mexico, 191/754; Panama, 35/89; Venezuela, 36/209; Latin America, $1045 / 2962 .{ }^{a}$ Data from El Salvador, Jamaica and Nicaragua are not included in the analysis by country because fewer than 50 isolates were collected; however, their data are included in the total for Latin America.

from centers in Latin America between 2004 and 2010. It provides an update to the work of Rossi et al. [7] who reported on Gram-negative and Gram-positive organisms collected as part of T.E.S.T. between 2004 and 2007. The isolates reported on by Rossi et al. [7] are also included in the dataset studied in this report. Rates of ESBL-producing E. coli and K. pneumoniae are similar to the mentioned study and are also similar to those reported by Villegas et al. [3] for Latin American isolates collected in 2008 as part of the SMART study.

This study shows important variations in the rate of ESBL production by country, reaching values around $40 \%$ in E. coli and $>50 \%$ for K. pneumoniae, which are similar to those observed in the Asia/Pacific region by Farrell et al. [12] for both organisms and by Hawser et al. 2009 [13] for E. coli. However, it should be noted that these rates may be affected by the type of infection and population analyzed in each particular center or even by ward [2]. Considering that these are common nosocomial pathogens causing severe morbidity and mortality in critically ill patients and that the available choices of antibiotic treatments for these microorganisms are seriously reduced, there is increasing clinical concern for successful patient management where ESBL isolates are prevalent. Antimicrobial susceptibility rates were lower among ESBL-producing isolates when compared with non-ESBL producers with the exception of tigecycline, imipenem and meropenem where little or no changes in susceptibility $(<6.0 \%)$ were observed between both groups. ESBLproducing $K$. pneumoniae are frequently associated with multidrug resistance [14]. In particular, susceptibility to commonly-used antimicrobials including piperacillintazobactam and fluoroquinolones was reduced among ESBL-producing isolates. The worrying increase in resistance to these antibiotics among ESBL-producing organisms has been associated with the simultaneous presence of other resistance determinants [15-17]. The most common risk factor for resistance to fluoroquinolones in ESBL-producing strains is a previous history of high-level consumption of both extended-spectrum cephalosporin and quinolone antibiotics. These antibiotics are widely used in the region: Wirth et al. reported an increased use of fluoroquinolones in Latin America over a period of 10 years (1997-2007), where in some countries consumption doubled or even tripled [18].

It has been previously reported that tigecycline and carbapenems, along with amikacin, are highly active against the Enterobacteriaceae collected from countries in Latin American $[19,20]$. In the current study, susceptibility to tigecycline ranged between $99.8 \%$ against ESBL-producing $E$. coli to $93.7 \%$ against ESBLproducing K. pneumoniae. Imipenem susceptibility ranged between $100 \%$ against $K$. oxytoca to $91.7 \%$ against $S$. marcescens and meropenem susceptibility ranged between $98.6 \%$ against non-ESBL-producing $E$. coli to 89.0\% against ESBL-producing K. pneumoniae. The range of tigecycline MICs was greater than reported by Rossi et al. [7] against E. coli, K. pneumoniae, and Enterobacter spp.; however, this was due to single isolates at the top of the testing range (MIC $\geq 32 \mathrm{mg} / \mathrm{L}$ ). 
Table 2 Antimicrobial susceptibility (\%S) to the carbapenems among Gram-negative organisms collected from individual countries (2004 - 2010)

\begin{tabular}{|c|c|c|c|c|c|c|c|c|c|c|}
\hline \multirow[b]{2}{*}{ Antimicrobial } & & \multicolumn{9}{|c|}{ Country } \\
\hline & & Argentina & Brazil & Chile & Colombia & Guatemala & Honduras & Mexico & Panama & Venezuela \\
\hline \multicolumn{11}{|c|}{ non-ESBL E. coli } \\
\hline \multirow[t]{2}{*}{ Imipenem } & $\mathrm{N}$ & $216 / 219$ & $40 / 40$ & $47 / 47$ & $67 / 71$ & - & - & $64 / 64$ & - & $21 / 21$ \\
\hline & $\% \mathrm{~S}$ & 98.6 & 100 & 100 & 94.4 & - & - & 100 & - & 100 \\
\hline \multirow[t]{2}{*}{ Meropenem } & $N$ & $448 / 449$ & $164 / 164$ & $130 / 130$ & $386 / 390$ & $174 / 182$ & $45 / 46$ & $569 / 582$ & $84 / 84$ & $165 / 165$ \\
\hline & $\% \mathrm{~S}$ & 99.8 & 100 & 100 & 99.0 & 95.6 & 97.8 & 97.8 & 100 & 100 \\
\hline \multicolumn{11}{|l|}{ ESBL E. coli } \\
\hline \multirow[t]{2}{*}{ Imipenem } & $N$ & $28 / 29$ & $10 / 10$ & $29 / 29$ & $17 / 18$ & - & - & $51 / 52$ & - & - \\
\hline & $\% \mathrm{~S}$ & 96.6 & 100 & 100 & 94.4 & - & - & 98.1 & - & \\
\hline \multirow[t]{2}{*}{ Meropenem } & $\mathrm{N}$ & $71 / 72$ & $32 / 33$ & $65 / 65$ & $38 / 40$ & $76 / 81$ & $30 / 31$ & $337 / 346$ & $16 / 16$ & $27 / 29$ \\
\hline & $\% \mathrm{~S}$ & 98.6 & 97.0 & 100 & 95.0 & 93.8 & 96.8 & 97.4 & 100 & 93.1 \\
\hline \multicolumn{11}{|c|}{ non-ESBL $K$. pneumoniae } \\
\hline \multirow[t]{2}{*}{ Imipenem } & $\mathrm{N}$ & $120 / 121$ & $17 / 17$ & $29 / 29$ & $34 / 35$ & - & - & $47 / 47$ & - & $10 / 10$ \\
\hline & $\% \mathrm{~S}$ & 99.2 & 100 & 100 & 97.1 & - & - & 100 & - & 100 \\
\hline \multirow[t]{2}{*}{ Meropenem } & $\mathrm{N}$ & $297 / 303$ & $88 / 92$ & $63 / 67$ & $290 / 316$ & $83 / 93$ & $16 / 20$ & $495 / 516$ & $53 / 54$ & $156 / 163$ \\
\hline & $\% \mathrm{~S}$ & 98.0 & 95.7 & 94.0 & 91.8 & 89.2 & 80.0 & 95.9 & 98.1 & 95.7 \\
\hline \multicolumn{11}{|c|}{ ESBL K. pneumoniae } \\
\hline \multirow[t]{2}{*}{ Imipenem } & $\mathrm{N}$ & $91 / 93$ & $20 / 23$ & $35 / 35$ & $16 / 18$ & - & - & $19 / 19$ & - & - \\
\hline & $\% \mathrm{~S}$ & 97.8 & 87.0 & 100 & 88.9 & - & - & 100 & - & - \\
\hline \multirow[t]{2}{*}{ Meropenem } & $\mathrm{N}$ & 170/177 & 78/82 & 102/112 & $47 / 63$ & $76 / 96$ & $50 / 55$ & $160 / 172$ & $32 / 35$ & $28 / 31$ \\
\hline & $\% \mathrm{~S}$ & 96.0 & 95.1 & 91.1 & 74.6 & 79.2 & 90.9 & 93.0 & 91.4 & 90.3 \\
\hline \multicolumn{11}{|l|}{ K. oxytoca } \\
\hline \multirow[t]{2}{*}{ Imipenem } & $\mathrm{N}$ & $32 / 32$ & - & - & $13 / 13$ & - & - & $11 / 11$ & - & - \\
\hline & $\% \mathrm{~S}$ & 100 & - & - & 100 & - & - & 100 & - & - \\
\hline \multirow[t]{2}{*}{ Meropenem } & $\mathrm{N}$ & $38 / 38$ & $17 / 17$ & $15 / 15$ & $37 / 38$ & - & - & $106 / 110$ & - & - \\
\hline & $\% \mathrm{~S}$ & 100 & 100 & 100 & 97.4 & - & - & 96.4 & - & - \\
\hline \multicolumn{11}{|c|}{ Enterobacter spp. } \\
\hline \multirow[t]{2}{*}{ Imipenem } & $\mathrm{N}$ & $210 / 222$ & $44 / 47$ & $58 / 58$ & $56 / 59$ & - & - & $58 / 58$ & - & $25 / 25$ \\
\hline & $\% \mathrm{~S}$ & 94.6 & 93.6 & 100 & 94.9 & - & - & 100 & - & 100 \\
\hline \multirow[t]{2}{*}{ Meropenem } & $\mathrm{N}$ & $494 / 502$ & 187/195 & $161 / 171$ & $347 / 384$ & $83 / 105$ & $29 / 34$ & $622 / 651$ & $66 / 70$ & $176 / 183$ \\
\hline & $\% \mathrm{~S}$ & 98.4 & 95.9 & 94.2 & 90.4 & 79.0 & 85.3 & 95.5 & 94.3 & 96.2 \\
\hline \multicolumn{11}{|l|}{ S. marcescens } \\
\hline \multirow[t]{2}{*}{ Imipenem } & $\mathrm{N}$ & $83 / 91$ & $18 / 20$ & $30 / 31$ & $37 / 41$ & - & - & $23 / 26$ & - & $10 / 11$ \\
\hline & $\% \mathrm{~S}$ & 91.2 & 90.0 & 96.8 & 90.2 & - & - & 88.5 & - & 90.9 \\
\hline \multirow[t]{2}{*}{ Meropenem } & $\mathrm{N}$ & $203 / 210$ & $77 / 78$ & 70/71 & $138 / 144$ & $42 / 45$ & $14 / 15$ & $220 / 234$ & $25 / 25$ & $69 / 70$ \\
\hline & $\% \mathrm{~S}$ & 96.7 & 98.7 & 98.6 & 95.8 & 93.3 & 93.3 & 94.0 & 100 & 98.6 \\
\hline A. baumannii & & & & & & & & & & \\
\hline Imipenem & $\mathrm{N}$ & $72 / 148$ & $13 / 30$ & $35 / 39$ & $21 / 35$ & - & - & $30 / 30$ & - & $7 / 11$ \\
\hline & $\% \mathrm{~S}$ & 48.6 & 43.3 & 89.7 & 60.0 & - & - & 100 & - & 63.6 \\
\hline Meropenem & $\mathrm{N}$ & $48 / 321$ & $29 / 118$ & $37 / 139$ & $95 / 220$ & $43 / 141$ & $14 / 51$ & 202/333 & $8 / 48$ & $21 / 96$ \\
\hline & $\% \mathrm{~S}$ & 15.0 & 24.6 & 27.0 & 43.2 & 30.4 & 27.5 & 60.7 & 16.7 & 21.9 \\
\hline
\end{tabular}

${ }^{\mathrm{a}}$ Data on El Salvador, Jamaica and Nicaragua not included in the analysis by country because fewer than 50 isolates collected.

It is worth noting that resistance to meropenem has been observed across Latin America among members of the Enterobacteriaceae. The situation may not appear as poor for imipenem, with higher rates of susceptibility reported. However, it should be noted that imipenem susceptibility testing stopped in 2006 and switched to meropenem, meaning that the results for meropenem give a more current picture of carbapenem susceptibility 
in Latin America. In the late 1990s and early part of the $21^{\text {st }}$ century, carbapenem resistance in Enterobacteriaceae was infrequent and resistance mechanisms were related to the presence of ESBL or overproduction of AMP-C $\beta$-lactamases associated with reduced outer membrane permeability [21,22]. Enterobacteriaceae producing carbapenemases were first reported in the USA [23] and have now been reported in various parts of the world, including several countries in Latin America where class A carbapenemase KPC-2 enzymes are prevalent [5,24-26]. The results of this study, along with reports of decreasing susceptibility to imipenem among Klebsiella spp. in Latin America [27] demonstrate the importance of antimicrobial resistance surveillance and further analysis of the carbapenem-resistant Enterobacteriaceae identified in this dataset is warranted.

$H$. influenzae are frequently susceptible to available antimicrobials. In this study susceptibility was $>98 \%$ to the agents tested, with the exception of ampicillin (78.7\% susceptible) largely due to the production of $\beta$ lactamase. This is in agreement with the global T.E.S.T. findings published by Garrison et al. [28].

A. baumannii is a problematic organism frequently associated with multidrug resistance and $33.2 \%$ of the isolates in this study were defined as such. The antimicrobial with the highest rate of susceptibility against the whole A. baumannii population was minocycline. Tigecycline was also active, with $95.8 \%$ of isolates displaying an MIC $\leq 2 \mathrm{mg} / \mathrm{L}$. These results are similar to those reported by Rossi et al. [7] for Latin America isolates collected between 2004 and 2007 and Garrison et al. [24] who reported on a global collection from the T.E.S.T. study collected between 2004 and 2007. Susceptibility to the carbapenems was $62.5 \%$ for imipenem and $33.9 \%$ for meropenem which are lower than the global rates reported by Garrison et al. $(82.3 \%$ and $59.0 \%$, respectively) and lower than the Latin American rates reported by Gales et al. [29] for Acinetobacter spp. collected between 2001 and 2004 (86.4\% and 83.6\%, respectively). Susceptibility also varied by country, Tognim et al. [30] reported as part of the SENTRY study that carbapenem resistance among Acinetobacter spp. varied between countries within Latin America with Argentina a particular 'hot spot' of resistance. Our results suggest this is a continuing situation with the lowest rates of susceptibility to meropenem reported among isolates from Argentina.

\section{Conclusions}

Surveillance of antimicrobial susceptibility plays a key role in guiding appropriate antimicrobial therapy. In this study the carbapenems and tigecycline continue to be active against the Enterobacteriaceae and A. baumannii; however, there is cause for concern with carbapenem non-susceptible isolates reported in all countries included in this study. The in vitro activity $\left(\mathrm{MIC}_{90}\right)$ of tigecycline was similar to that reported for isolates collected during Phase 3 clinical trials [31].

\section{Competing interests}

LFC has received speaking fees from Wyeth Pharmaceuticals (which was acquired by Pfizer Inc. in October 2009). MJD is an employee of Pfizer Inc.

\section{Authors' contributions}

LFC was involved in data collection, data interpretation and drafting and reviewing of the manuscript; MJD was involved in study design and participated in data interpretation and the drafting and review of the manuscript. All authors read and approved the final manuscript.

\section{Acknowledgements}

The authors wish to acknowledge and thank the Latin American T.E.S.T. investigators and laboratories for their participation in this study, as well as the staff at IHMA for their coordination of T.E.S.T and Dr. Marcela Radice for revision of and critical discussion regarding this manuscript. This study was sponsored by Pfizer Inc.

No authors were paid for their contributions to this manuscript. Medical writing support was provided by Wendy Hartley PhD at Micron Research Ltd, Chatteris, UK and was funded by Pfizer Inc. Micron Research Ltd also provided data management services which were funded by Pfizer Inc.

\section{Author details}

'Laboratorio de Microbiología, Hospital Aleman, Pueyrredón 1640, PB, Ciudad Autónoma de Buenos Aires, Argentina. ${ }^{2}$ Pfizer Inc, 500 Arcola Road; E-Dock, Collegeville, PA 19426, USA.

Received: 27 April 2012 Accepted: 29 September 2012 Published: 22 October 2012

\section{References}

1. Moet GJ, Jones RN, Biedenbach DJ, Stilwell MG, Fritsche TR: Contemporary causes of skin and soft tissue infections in North America, Latin America, and Europe: report from the SENTRY Antimicrobial Surveillance Program (1998-2004). Diagn Microbiol Infect Dis 2007, 57:7-13.

2. Villegas MV, Kattan JN, Quinteros MG, Casellas JM: Prevalence of extendedspectrum $\beta$-lactamases in South America. Clin Microbiol Infect 2008, 14(Suppl 1):154-158.

3. Villegas MV, Blanco MG, Sifuentes-Osornio J, Rossi F: Increasing prevalence of extended-spectrum- $\beta$-lactamase among Gram-negative bacilli in Latin America - 2008 update from the Study for Monitoring Antimicrobial Resistance Trends (SMART). Braz J Infect Dis 2011, 15:34-39.

4. Dhillon RHP, Clark J: ESBLs: a clear and present danger? Crit Care Res Pract 2012, 2012:625170. Epub 2011 Jun 6.

5. Gomez SA, Pasteran FG, Faccone D, Tijet N, Rapoport M, Lucero C, Lastovetska O, Albornoz E, Galas M, KPC Group, Melano RG, Corso A, Petroni A: Clonal dissemination of Klebsiella pneumoniae ST258 harbouring KPC-2 in Argentina. Clin Microbiol Infect 2011, 17:1520-1524.

6. Neonakis IK, Spandidos DA, Petinaki E: Confronting multidrug-resistant Acinetobacter baumannii: a review. Int I Antimicrob Agents 2011, 37:102-109.

7. Rossi F, García P, Ronzon B, Curcio D, Dowzicky MJ: Rates of antimicrobial resistance in Latin America (2004-2007) and in vitro activity of the glycylcycline tigecycline and of other antibiotics. Braz J Infect Dis 2008, 12:405-415.

8. Clinical and Laboratory Standards Institute: Methods for dilution antimicrobial susceptibility tests for bacteria that grow aerobically, Approved standard. 8th edition. PA: Document M7-A8. Clinical and Laboratory Standards Institute Wayne; 2009. ISBN ISBN 1-56238-689-1.

9. Clinical and Laboratory Standards Institute: Performance standard for antimicrobial susceptibility testing: 20th information supplement. Document M100-S20. Wayne, PA: Clinical and Laboratory Standards Institute; 2010.

10. Clinical and Laboratory Standards Institute: Performance standard for antimicrobial susceptibility testing: 20th informational supplement (June 2010 
update). Wayne, PA: Document M100-S20U, Clinical and Laboratory Standards Institute: 2010

11. Tygacil ${ }^{\circledR}$ Product Insert. http://www.pfizerpro.com/hcp/tygacil

12. Farrell DJ, Turnidge JD, Bell J, Sader HS, Jones RN: The in vitro evaluation of tigecycline tested against pathogens isolates in eight countries in the Asia-Western Pacific region (2008). J Infect 2010, 60:440-451.

13. Hawser SP, Bouchillon SK, Hoban DJ, Badal RE, Hsueh PR, Paterson DL: Emergence of high levels of extended-spectrum- $\beta$-lactamase-producing gram-negative bacilli in the Asia-Pacific region: data from the Study for Monitoring Antimicrobial Resistance Trends (SMART) program, 2007. Antimicrob Agents Chemother 2009, 53:3280-3284.

14. Mosqueda-Gómez JL, Montaño-Loza A, Rolón AL, Cervantes C, Bobadilladel-Valle JM, Silva-Sánchez J, Garza-Ramos U, Villasís-Keever A, Galindo-Fraga A, Palacios GM, Ponce-de-León A, Sifuentes-Osornio J: Molecular epidemiology and risk factors of bloodstream infections caused by extendedspectrum $\beta$-lactamase-producing Klebsiella pneumoniae A case-control study. Int J Infect Dis 2008, 12:653-659.

15. Paterson DL, Bonomo RA: Extended-spectrum beta-lactamases: a clinical update. Clin Microbiol Rev 2005, 18:657-686.

16. Martinez-Martinez L, Pascual A, Conejo Mdel C, Garcia I, Joyanes P, Domenech-Sanchez A, Benedi VJ: Energy-dependent accumulation of norfloxacin and porin expression in clinical isolates of Klebsiella pneumoniae and relationship to extended-spectrum beta-lactamase production. Antimicrob Agents Chemother 2002, 46:3926-3932.

17. Patterson JE, Hardin TC, Kelly CA, Gracia RC, Jorgensen JH: Association of antibiotic utilization measures and control of multiple-drug resistance in Klebsiella pneumoniae. Infect Control Hosp Epidemiol 2000, 21:455-458.

18. Wirtz VJ, Dreser A, Gonzales R: Trends in antibiotic utilization in eight Latin American countries, 1997-2007. Rev Panam Salud Publica 2010, 27:219-225

19. Fernández Canigia L, Kaufman S, Lanata L, Vay C, Giovanakis M, Bantar C, Argentinean Tigecycline Surveillance Group: Multicenter study to assess the in vitro activity of tigecycline by disk diffusion test against clinical isolates from Argentina. Chemotherapy 2009, 55:20-27.

20. Bantar C, Curcio D, Fernández Canigia L, García P, Guzmán Blanco M, Leal AL, Latin American Tigecycline Surveillance Group: Comparative in vitro activity of tigecycline against bacteria recovered from clinical specimens in Latin America. J Chemother 2009, 21:144-152.

21. Melano R, Corso A, Petroni A, Centron D, Orman B, Pereyra A, Moreno N, Galas M: Multiple antibiotic-resistance mechanisms including a novel combination of extended-spectrum $\beta$-lactamases in a Klebsiella pneumoniae clinical strain isolated in Argentina. J Antimicrob Chemother 2003, 52:36-42.

22. Martínez-Martínez L, Pascual A, Hernández-Allés $\mathrm{S}$, Alvarez-Diaz D, Suárez Al, Tran J, Benedí VJ, Jacoby GA: Roles of $\beta$-lactamases and porins in activities of carbapenems and cephalosporins against Klebsiella pneumoniae. Antimicrob Agents Chemother 1999, 43:1669-1673.

23. Bratu S, Landman D, Haag R, Recco R, Eramo A, Alam M, Quale J: Rapid spread of carbapenem-resistant Klebsiella pneumoniae in New York City: a new threat to our antibiotic armamentarium. Arch Intern Med 2005, 165:1430-1435.

24. Radice M, Power P, Gutkind G, Fernández K, Vay C, Famiglietti A, Ricover N Ayala JA: First class $\mathrm{A}$ carbapenemase isolates from Enterobacteriaceae in Argentina. Antimicrob Agents Chemother 2004, 48:1068-1069.

25. Pasteran FG, Otaegui L, Guerriero L, Radice G, Maggiora R, Rapoport M Faccone D, Di Martino A, Galas M: Klebsiella pneumoniae carbapenemase2, Buenos Aires, Argentina. Emerg Infect Dis 2008, 14:1178-1180.

26. Villegas MV, Lolans K, Correa A, Suarez CJ, Lopez JA, Vallejo M, Quinn JP, The Colombian Nosocomial Resistance Study Group: First detection of the plasmid-mediated class A carbapenemase KPC-2 in clinical isolates of Klebsiella pneumoniae from South America. Antimicrob Agents Chemother 2006, 50:2880-2882.

27. Gales AC, Jones RN, Sader HS: Contemporary activity of colistin and polymyxin B against a worldwide collection of Gram-negative pathogens: results from the SENTRY antimicrobial surveillance program (2006-2009). J Antimicrob Chemother 2011, 66:2070-2074.

28. Garrison MW, Mutters R, Dowzicky MJ: In vitro activity of tigecycline and comparator agents against a global collection of Gram-negative and Gram-positive organisms: tigecycline Evaluation and Surveillance Trial 2004 to 2007. Diagn Microbiol Infect Dis 2009, 65:288-299.
29. Gales $A C$, Jones RN, Sader HS: Global assessment of the antimicrobial activity of polymyxin B against 54731 clinical isolates of Gram-negative bacilli: report from the SENTRY antimicrobial surveillance programme (2001-2004). Clin Microbiol Infect 2006, 12:315-321.

30. Tognim MC, Andrade SS, Silbert S, Gales AC, Jones RN, Sader HS: Resistance trends of Acinetobacter spp. in Latin America and characterization of international dissemination of multi-drug resistant strains: five-year report of the SENTRY Antimicrobial Surveillance Program. Int I Infect Dis 2004, 8:284-291.

31. Bradford PA, Weaver-Sands DT, Petersen PJ: In vitro activity of tigecycline against isolates from patients enrolled in Phase 3 clinical trials of treatment for complicated skin and skin-structure infections and complicated intra-abdominal infections. Clin Infect Dis 2005, 41:S315-S332

doi:10.1186/1476-0711-11-29

Cite this article as: Fernández-Canigia and Dowzicky: Susceptibility of important Gram-negative pathogens to tigecycline and other antibiotics in Latin America between 2004 and 2010. Annals of Clinical Microbiology and Antimicrobials 2012 11:29.

\section{Submit your next manuscript to BioMed Central and take full advantage of:}

- Convenient online submission

- Thorough peer review

- No space constraints or color figure charges

- Immediate publication on acceptance

- Inclusion in PubMed, CAS, Scopus and Google Scholar

- Research which is freely available for redistribution 